\title{
HUBUNGAN PENCEMARAN KARBON MONOKSIDA DALAM RUMAH DENGAN KEJADIAN ISPA DI DESA SUNGAI ALAT KABUPATEN BANJAR
}

\author{
Imam Santoso, Darmiah \\ Poltekkes Kemenkes Banjarmasin Jurusan kesehatan Lingkungan Banjarbaru \\ Jl. H. M. Cokrokusumo No. 1A Kota Banjarbaru \\ Email: imamsantoso165@gmail.com
}

\begin{abstract}
Relationship of Carbon Monoxide Pollution in House With The Upper Respiratory Tract infection In Desa Sungai Alat Kabupaten Banjar. The data showed $64.2 \%$ of households in South Kalimantan residents use charcoal and firewood for cooking, so the room in a house filled with smoke. In addition to the state of the smoke could also come from outside, because the habits of the people who set fire to dry land in the dry season. This phenomenon is predicted to be potential risk of respiratory tract infections. This study aims to determine the relationship of carbon monoxide pollution in homes with the upper respiratory tract infection in Desa Sungai Alat Kabupaten Banjar. Using cross sectional study design. The number of samples taken 28 infants in total population. Analysis used logistic regression. The results of the research data showed levels of CO in the average house of $0.42 \mathrm{mg} / \mathrm{m} 3$ in the range of 0.19 to $1.62 \mathrm{mg} / \mathrm{m} 3$. The number of infants who suffer from respiratory $42.9 \%$. Houses that use firewood as much as $53.6 \%$, and home to the unhealthy category as much as $78.6 \%$. Temperatures in the average home $32.60 \mathrm{C}$, and air humidity in the average home $71.41 \%$. Bivariate analysis using logistic regression, there was no significant association between levels of $\mathrm{CO}$ with the upper respiratory tract infection in infants ; similarly no significant association between the control variables with the dependent variable. To do a home assessment form should be conducted validity assessment. In further studies the expected number of samples propagated to the toddler .
\end{abstract}

Keywords : pollution, carbon monoxide, upper respiratory tract infection

Abstrak : Hubungan Pencemaran Karbon Monoksida dalam Rumah dengan Kejadian ISPA di Desa Sungai Alat Kabupaten Banjar. Data menunjukkan 64,2\% rumah tangga penduduk Kalimantan Selatan menggunakan arang dan kayu bakar untuk memasak, sehingga ruangan dalam rumah dipenuhi asap. Selain keadaan tersebut asap bisa juga berasal dari luar, karena kebiasaan masyarakat yang membakar lahan kering di musim kemarau. Fenomena tersebut diprediksi akan berpotensi menimbulkan risiko terjadinya infeksi saluran pernafasan. Penelitian ini bertujuan mengetahui hubungan pencemaran karbon monoksida dalam rumah dengan kejadian ISPA di Desa Sungai Alat Kabupaten Banjar. Desain penelitian menggunakan Cross Sectional. Jumlah sampel 28 bayi yang diambil secara total populasi. Analisis menggunakan uji regresi logistik. Hasil penelitian diperoleh data kadar CO didalam rumah ratarata $0,42 \mathrm{mg} / \mathrm{m}^{3}$ pada kisaran $0,19-1,62 \mathrm{mg} / \mathrm{m}^{3}$. Jumlah bayi yang menderita ISPA sebanyak 42,9\%. Rumah yang menggunakan kayu bakar sebanyak 53,6\%, dan rumah dengan kategori tidak sehat sebanyak $78,6 \%$. Suhu udara dalam rumah rata-rata $32,6{ }^{\circ} \mathrm{C}$, dan kelembaban udara dalam rumah rata-rata $71,41 \%$. Analisis bivariat dengan menggunakan uji regresi logistik, tidak ada hubungan yang bermakna antara kadar CO dengan kejadian ISPA pada bayi; demikian pula tidak hubungan yang bermakna antara variabel kontrol dengan variabel terikat. Untuk melakukan penilaian rumah form penilaian hendaknya dilakukan uji validitas. Pada penelitian lanjutan diharapkan jumlah sampel diperbanyak sampai pada balita.

Kata kunci : pencemaran, karbon monoksida, ISPA. 


\section{PENDAHULUAN}

Ruangan dalam rumah merupakan suatu tempat manusia beraktifitas. Kalau diperhatikan waktu yang dihabiskan manusia di dalam ruangan jauh lebih lama dibandingkan di udara terbuka. Jika manusia berada di dalam ruangan dengan sirkulasi lingkungan udara yang buruk, maka perlu diperhatikan kualitas udaranya dan kemungkinan terakumulasi bahan pencemar, seperti Oksida Nitrogen, Carbon monoksida, Formaldehid. Bahan-bahan pencemar tersebut dapat memberikan pengaruh negatif terhadap kesehatan manusia yang ada di dalam ruangan tersebut. Sumber bahan pencemar dalam ruangan bisa berasal dari aktifitas manusia sendiri, seperti berasal dari asap tembakau, kegiatan memasak di dapur, insektisida/pestisida, dan pembersih ruangan [1][2][3].

Studi United State Environmental Protection Agency (US-EPA) tentang peluang manusia terpapar polusi dalam ruangan mengindikasikan bahwa derajat polusi dalam ruang bisa dua kali sampai lima kali lebih tinggi diabandingkan dengan polusi luar ruang. Lembaga EPA tersebut juga menempatkan polusi udara dalam ruang sebagai satu dari lima besar polusi yang berisiko mengancam kesehatan masyarakat modern [4]

Hasil Riset Kesehatan Dasar 2010 di Provinsi Kalimantan Selatan masih ditemukan $71,9 \%$ rumah kurang sehat dari 1.236 rumah tangga sampel. Penggunaan bahan bakar terdapat $64,2 \%$ rumah tangga menggunakan arang dan kayu bakar untuk memasak, sehingga ruangan dalam rumah dipenuhi asap. Selain keadaan tersebut asap bisa juga berasal dari luar, karena kebiasaan masyarakat yang membakar sampah dan lahan yang kering. Fenomena tersebut diprediksi akan berpotensi menimbulkan risiko terjadinya infeksi saluran pernafasan [5]. Selain Terkait kualitas udara dalam ruangan (terutama dalam rumah tangga) di Kabupaten Banjar terdapat kasus ISPA sebesar 30,04\% dari 574 rumah tangga, angka tersebut telah melebihi prevalensi Provinsi (27,06\%). Seiring dengan kasus infeksi saluran pernafasan, prevalensi pneumonia sebesar $3,82 \%$ juga telah melebihi angka Provinsi
$(2,26 \%)$. Kabupaten Banjar merupakan salah satu kabupaten yang mempunyai angka melebihi provinsi dari tujuh kabupaten [6].

\section{BAHAN DAN CARA PENELITIAN}

Desain penelitian yang digunakan penulis adalah penelitian Analitik dengan pendekatan Cross Sectional [7]. Penelitian mengambil lokasi di Desa Sungai Alat Kecamatan Astambul Kabupaten Banjar. Dilaksanakan mulai bulan Juli s/d Oktober 2012.

Populasi penelitian adalah semua rumah yang ada bayi di Desa Sei Alat Wilayah kerja Puskesmas Astambul Kecamatan Astambul Kabupaten Banjar. Sampel diambil secara total populasi terhadap semua rumah yang ada bayi di Desa Sei Alat Kecamatan Astambul Kabupaten Banjar, berjumlah 28 bayi.

Pengukuran dan pemeriksaan variabel Kelembaban, Suhu, dan karbon monoksida (CO) dilakukan oleh Laboratorium BTKL Banjarmasin, diagnosa penyakit dilakukan oleh petugas kesehatan yang menangani Program P2 ISPA Puskesmas Astambul dan Bidan Desa Sungai Alat, observasi rumah dengan Form pemeriksaan rumah oleh mahasiswa Kesehatan Lingkungan dan petugas Sanitarian Puskesmas.

Analisis Univariat untuk melihat distribusi frekuensi masing-masing variabel yang telah ditentukan dalam penelitian [8], dan Analisis Bivariat untuk melihat perbedaan proporsi, hubungan antara variabel bebas dengan terikat, dan variabel konfonding menggunakan Uji Regresi Logistik [9][10].

\section{HASIL PENELITIAN DAN PEMBAHASAN}

\section{A. Hasil Penelitian}

1. Analisis Univariat

Jenis Kelamin Bayi di Desa Sungai Alat sama banyaknya antara laki-laki 14 bayi $(50 \%)$ dan perempuan 14 bayi (50\%). Umur Bayi rata-rata (mean) 6,43 bulan, umur termuda 2 bulan dan umur tertua 11 bulan.

Rata-rata (mean) kadar CO dalam rumah responden $0,42 \mathrm{mg} / \mathrm{m}^{3}$, dengan besar rentang (range) $1,4342 \mathrm{mg} / \mathrm{m}^{3}$. Angka 
minimum $0,1942 \mathrm{mg} / \mathrm{m}^{3}$ dan maksimum $1,6242 \mathrm{mg} / \mathrm{m}^{3}$.

Bahan bakar memasak yang digunakan responden terbanyak adalah kayu bakar $(53,6 \%)$ dan Non kayu bakar $(46,4 \%)$.

Hasil survei yang dilakukan terhadap rumah bayi dapat dikategorikan dominan tidak sehat $(78,6 \%)$ dan Kurang sehat $(21,4 \%)$. Suhu ruang pada masing-masing rumah responden rata-rata $32,6^{\circ} \mathrm{C}$. Kelembaban relatif pada ruang terukur nilai rata-rata $71,41 \%$; dengan nilai rentang antara $64,5 \%-79,9 \%$.

Hasil pemeriksaan yang dilakukan terhadap bayi menunjukkan status bayi yang sehat lebih banyak $(57,1 \%)$ dari pada sakit ISPA (42,9\%).
2. Analisis Bivariat

a. Hubungan antara varisbel bebas dengan variabel terikat.

Analisis bivariat antara variabel bebas (CO) dengan variabel terikat (ISPA) menggunakan Uji Regresi Logistik Sederhana, diperoleh nilai $\mathrm{p}=0,467$ pada tingkat kemaknaan $(\alpha=0,05)$; berarti tidak ada hubungan yang signifikan antara gas CO dengan kejadian ISPA pada bayi. Untuk ikut serta dalam Analisis Multivariat, maka variabel kandidat perlu dua pertimbangan; (1) harus mempunyai nilai $p<0,25$ dan (2) melihat asumsi keilmuan [11]. Hasil perhitungan selengkapnya dapat dilihat pada Tabel dibawah ini :

Tabel 1. Hasil Analisis Bivariat CO dengan Kejadian ISPA pada bayi di Desa Sungai Alat Kab. Banjar Oktober 2012

\begin{tabular}{cccr}
\hline Variabel & Wald & \multicolumn{1}{l}{$\mathrm{p}_{\text {value }}$} & OR \\
\hline CO & 0,528 & 0,467 & 5,514 \\
\hline
\end{tabular}

b. Hubungan antara variabel konfonding dengan variabel terikat.

Analisis bivariat antara variabel konfonding dengan variabel terikat menggunakan Uji
Regresi Logistik. Hasil perhitungan masingmasing variabel konfonding tersebut dapat dilihat pada tabel di bawah ini :

Tabel 2. Hasil Analisis Bivariat Variabel Konfonding dengan Variabel Terikat pada bayi di Desa Sungai Alat Kab. Banjar Oktober 2012

\begin{tabular}{llrrr}
\hline No. & \multicolumn{1}{c}{ Variabel } & Wald & \multicolumn{1}{c}{$\mathrm{p}_{\text {value }}$} & \multicolumn{1}{c}{ OR } \\
\hline 1. & Bahan Bakar & 0,108 & 0,743 & 0,778 \\
& Memasak & & & \\
2. & Kategori Rumah & 1,658 & 0,198 & 0,286 \\
3. & Suhu Ruangan & 1,966 & 0,161 & 1,619 \\
4. & Kelembaban & 0,107 & 0,744 & 0,967 \\
& Ruangan & & & \\
\hline
\end{tabular}

Tabel 2 diatas dapat dilihat semua variabel konfonding tidak dapat diikut sertakan dalam analisis multivariat, karena semua mempunyai nilai $\mathrm{p}>0,05$; artinya tidak ada hubungan variabel konfonding dengan variabel terikat. Oleh karena hasil analisis bivariat menunjukkan semua variabel bebas dan konfonding hasil nilai $p>0,05$ maka analisis multivariat tidak dilanjutkan. Asumsi penggunaan analisis multivariat adalah apabila terdapat 2 lebih nilai variabel yang signifikan (Adisasmita, 1992).

\section{B. Pembahasan}

Karbon Monoksida (CO) merupakan gas yang tidak berwarna, tidak berbau, mudah terbakar, dan bersifat toksik (Sitepoe,199712; Slamet,201113). Toksisitas berarti afinitasnya terhadap haemoglobin 200 kali lipat dibandingkan dengan oksigen 
dan menyerap radiasi inframerah (Sitepoe,199712). CO terbentuk dari hasil pembakaran tak sempurna bahan-bahan karbon. Sumber utama CO $(80 \%)$ berasal dari asap kendaraan bermotor, asap tembakau/rokok, kegiatan memasak di dapur. (Pudjiastuti,1998; Slamet,201113).

Penjelasan teori dan temuan-temuan hasil penelitian yang dilakukan oleh peneliti terdahulu tidak terbukti secara statistik pada penelitian ini, karena variabel bebas (CO) terhadap variabel terikat (ISPA) mempunyai nilai $\mathrm{p}>0,05$; artinya tidak ada hubungan antar Karbon Monoksida terhadap kejadian ISPA. Hasil penelitian ini hanya bisa menjelaskan secara deskriptif rata-rata (mean), dan nilai dispersi kadar CO dalam rumah. Hal lain yang dapat dijelaskan bahwa kisaran nilai CO antara $0,19-1,62 \mathrm{mg} / \mathrm{m}^{3}$, merupakan nilai yang diperoleh pada pengukuran sesaat tanpa memperhitungkan faktor-faktor lain, misalnya; kepadatan lalu lintas di desa, jarak rumah dengan jalan, dan kebiasaan merokok penghuni rumah. Karena faktor tersebut secara teoritis akan mempengaruhi tinggi rendahnya nilai CO dalam ruangan (indoor air pollution).

Jumlah bayi yang sehat lebih banyak dibandingkan dengan bayi yang menderita ISPA, namun rumah yang dikategorikan tidak sehat lebih banyak dibandingkan dengan rumah yang kurang sehat, dan hal ini seiring dengan rumah yang menggunakan kayu bakar lebih banyak dibandingkan dengan rumah yang tdak menggunakan kayu bakar. Hasil analisis bivariat menunjukkan tidak ada hubungan yang signifikan antara variabel konfonding (kayu bakar, kategori rumah) dengan variabel terikat (ISPA) pada nilai $p>0,05$.

Hasil penelitian ini tidak searah dengan hasil penelitian yang pernah dilakukan oleh peneliti terdahulu. Kassove ${ }^{14}$ (1993) pada anak-anak di Afrika Selatan, orang tua yang menggunakan kayu bakar ternyata berhubungan secara bermakna dengan kejadian ISPA pada anak. Penelitian Rahmi (2000), menunjukkan bahwa tingginya angka kesakitan ISPA pada balita berhubungan dengan kelembaban ruangan dan penggunaan kayu bakar dalam kegiatan memasak. Juga penelitian di Indramayu (Depkes, 200015), kematian bayi karena pnemonia, salah satunya penyebabnya anak yang lama di dapur bersama ibunya. Demikian pula penelitian Santoso (200116; $2002^{18}$ ), salah satu risiko timbulnya pnemonia berhubungan dengan penggunaan kayu bakar sebagai bahan bakar memasak.

Keadaan tersebut dapat dijelaskan bahwa kerangka konsep yang diajukan dalam penelitian ini secara statistik tidak bisa menjelaskan keterkaitan antara variabel konfonding dengan variabel terikat, walaupun telah mengacu pada kerangka teori yang sudah visibel. Ada kemungkinan jumlah sampel yang dimiliki tidak cukup untuk dilakukan analisis statistik infrensial, karena asumsi yang harus dipenuhi dalam jumlah sampel besar (lebih dari 30), tetapi sampel pada penelitian ini menggunakan sampel kecil. Juga sasaran penelitian tidak hanya pada bayi, tetapi juga pada balita, karena bayi dan balita sama-sama mempunyai risiko untuk terkena ISPA.

\section{KESIMPULAN DAN SARAN}

Hasil penelitian ini memberikan kesimpulan bahwa kadar gas CO dalam rumah berkisar 0,19-1,62 $\mathrm{mg} / \mathrm{m}^{3}$ dengan rata-rata $0,42 \mathrm{mg} / \mathrm{m}^{3}$. Bahan bakar yang digunakan untuk memasak dalam rumah tangga responden lebih banyak kayu bakar $(53,6 \%)$. Kategori rumah yang dimiliki oleh rumah tangga sampel lebih banyak rumah tidak sehat $(78,6 \%)$; dengan suhu dalam rumah berkisar $30,2^{\circ} \mathrm{C}-33,5^{\circ} \mathrm{C}$; dan kelembaban dalam rumah berkisar $64,5 \%$ $79,9 \%$. Jumlah bayi yang menderita ISPA sebanyak 42,9\%. Hasil analisis statistik baik variabel bebas dan variabel konfonding tidak berhubungan dengan kejadian ISPA pada bayi, sehingga penelitian ini tidak dapat membuktikan secara statistik adanya hubungan pencemaran karbon monoksida dalam rumah dengan kejadian ISPA di Desa Sungai Alat Kabupaten Banjar. Diharapkan pada penelitian berikutnya form penilaian rumah sebaiknya diuji coba terlebih dahulu meskipun sudah baku, karena untuk menjamin kualitas item penelitian. Untuk penelitian lanjutan disarankan menggunakan jumlah populasi yang lebih besar. 


\section{DAFTAR PUSTAKA}

1. Adisasmita, A, 1992, Strategi Pemodelan Pada Regresi Logistik. Dalam: Riono, P, dkk. Aplikasi Regresi Dalam Penelitian Kesehatan. Pusat Penelitian Kesehatan LP-UI. Jakarta. p:12.1 - 12.15

2. Aditama TY, 1992, Polusi Udara dan Kesehatan. Arcan. Jakarta

3. Ariawan Iwan, Besar dan Metode Sampel pada Penelitian Kesehatan, FKM-UI, 1998.

4. Ide Pangkalan, 2007, Inner Healing at Home, PT. Elex Media Komputindo, Jakarta,.

5. de Koning, H.W, et.al, 1987, Biomas Fuel Combustion and Health. Bulettin of The WHO No.63.

6. Kassove D, 1993, Smoke silled room and lower respiratory disease in infant, Souts African Medical Journal. 63:622624.

7. Kasjono HS, Editor, 2011, Penyehatan Pemukiman, Gosyen Publishing, Yogjakarta.

8. Pudjiastuti Lily, 1998, Kualitas udara dalam ruangan, Depdikbud, Jakarta.

9. Pratiknya AW, 2008, Dasar-dasar Metodologi Penelitian Kedokteran dan Kesehatan, PT. Raja Grafindo Persada, Jakarta,.

10. Prasetyo B dan Jannah LM, 2010, Metode Penelitian Kuantitatif, PT. Raja Grafindo Persada, Jakarta,.

11. Rao,M.N and Rao,H.V.N, 1994, Air Pollution. Tata McGraw-Hill Publishing Company Limited. New Delhi.

12. Santoso Imam, 2001, Hubungan konsentrasi debu udara ruang hunian dengan kejadian penyakit Pnemonia pada bayi dan balita di lingkungan pabrik semen PT. Indo Kodeko Cement di Desa Tarjun Kab. Kotabaru Kalsel. Tesis, FKM UI.

13. — 2002, Uji Regresi Logistik Ganda dalam menentukan risiko pnemonia balita pada Home Industry Meubel di Desa Ilir Masjid Kecamatan Amuntai Selatan, Politeknik Kesehatan, Banjarmasin,.

14. 2009, Sanitasi Perumahan Pemukiman, FK UNLAM, Banjarbaru.
15. Santoso, Singgih, 2003,Statistik Diskriptif Konsep dan Aplikasi dengan Microsoft Excel dan SPSS, Andi Offset, Yogyakarta.

16. Sabri Lunis, Hastono SP, 2007,Statistik Kesehatan, PT. Raja Grafindo Persada, Jakarta.

17. Slamet, Yuli Sumirat, 2011, Kesehatan Lingkungan, UGM Press, Yogyakarta. 